\title{
Self and History in Delmore Schwartz's Poetry and Criticism
}

Readers of Saul Bellow's latest novel will remember Von Humboldt Fleisher, paranoid extraordinary, whose perverse combination of destructive and benevolent energies assists the hero, Charlie Citrine, in reaching his own level of excess and ultimate self-knowledge. We all know by now that Delmore Schwartz was Bellow's model for Humboldt. Having known Delmore (no one who knew him can ever think of him as anything but Delmore, although as a student of his I never called him anything but Mr. Schwartz to his face), I can confirm that he had most of the magnetism so vividly described by Bellow. What Bellow did not convey so convincingly -perhaps because he was creating a character, not writing the biography of his old friend-was Delmore's consuming passion for his own vocation as a poet. Alas, Delmore wrote little poetry of consequence when I knew him at Syracuse (he was there from 1962 until shortly before his death in 1966). But he taught poetry and fiction and was one of a distinguished team of resident writers. What I should like to explore briefly here is my sense of this brilliant poet and critic who had a deeply painful awareness of the contradictions of his own personality.

I began to read Delmore's work in the summer of 1963. I had been asked by the Syracuse English Department to prepare a complete bibliography of his work for a collection of his essays which he was planning to bring out with Syracuse University Press. As Donald Dike and I note in the Preface to the Selected Essays, Delmore never accomplished his goal as editor of his own work. He never really started. This was probably owing more to his self-absorption than to any special literary fastidiousness. In any event, as I read his poems, stories, and essays back in 1963, I became fascinated by his work as a profound expression of the man I knew lumbering authoritatively but strangely around the halls of the humanities building and as the lugubrious or wildly entertaining monologist in the classroom or at student parties. I also came to see his work as a sometimes tentative, sometimes confident, groping toward the perfection of art he so admired in Joyce and Yeats, Stevens and Eliot. These were some of the modern masters that were his gods, about whom he talked endlessly and intimately with students, academic colleagues, and fellow writers. They-the masters -seemed to be constantly on his mind, companions with whom he carried on an incessant, energizing dialogue. 
Yet for him the oppressive reality of his life was his intensely painful manic-depression. His illness took the form, especially in the manic phase, of a paranoia that one can only call highly inventive. Struggling with his impulses-and the paranoia complicated his life in bizarre ways-became increasingly over the years his dominant obsession. In reading his notebooks (now at Yale University, with most of his other papers) years later, I was not really very astonished to read again and again his own accounts of his struggle. In an unpublished novel, Maxwelt' Crisis, the titular character (a mirror image of Delmore) says of himself in the midst of a depression:

He moved slowly, he was monotonous and dragging to others, and when he spoke he spoke in a low voice, almost a murmur, and he was unable to find the word or the memory he wanted. And sometimes, the worst times, his voice faltered and his lips visibly trembled as he tried to speak. Those who did not know him very well hardly knew the difference between this state, and the state of being normal and the contrary state of being elated, wild with energy, full of power and assurance.

Elsewhere, not too solemnly, his notebook comments on his sense of being doomed: "The Night my father got me / His mind was not upon me. I Destiny is Dynasty: The sins of the fathers / Are the years of the sons." Or a stark note of 1959:

I must think of the house on Ellery St. [in Cambridge]: where I lived alone, drank until I was [a] problem drinker, fell in love foolishly and vainly and wasted the years when I should have been at the height of my powers: during most of the Second World War and after.

Whether solemn or playful, these precisely objective remarks thread through twenty years of his notebooks, along with notations of conversations overheard in bars or at parties, or summaries of complex arguments in Whitehead and Aristotle, or elaborate pages filled with metrical exercises. But the deep melancholy in his self-observations is also part of his poetry. Even joyous passages, as in "The Kingdom of Poetry," are deeply tinged by fatalism. It is as if, true diagnostician that he was, he was constantly remembering his depression in the midst of his mania, and vice versa.

This melancholy is deeply rooted in Delmore's view of history and the growth of self. For him, man is constantly shaped by unconscious or dimly perceived forces-as the melancholy commentators of Genesis and Coriolanus point out. Delmore never fixed on the precise ideology for this view of history: he had many different versions and the Choruses reflect them. 
What is clear from his work is that he believed that against History and the Unconscious the individual can claim only an illusory sense of freedom. Yet he must choose in order to assert his creative power, his dignity. The melancholy tone and theme lie in the tension between this determinism and the assertion of the necessity of freedom. The supreme act of freedom for Delmore was the creative act itself-which either flowed with manic excess or was squeezed painfully from his torpor. He was said to have remarked: "I write when manic, revise when depressed."

In one of his most lyrical poems, "Abraham and Orpheus," this melancholy determinism expresses itself in a form that is quintessentially Delmorean. There is in the poem a very simple lyric repetition which circles around a simple theme: the exhaustion of love and the heavy presence of time as a defeating force. The central image is of circular movement. Abraham and Orpheus (the moral and poetic imperatives, if you like) are presented as figures who act out of love, mystery, and ignorance of consequences. Although their actions are "the substance of care," they are "poised on nothing, weighted on the air," and they have an intuitive knowledge or faith in the rightness, or perhaps only the inevitability, of their actions. Thus the poet can invoke their "learned presence" as a comfort in his dilemma. That dilemma is never specifically named, and this vagueness is typical of Delmore's poems. Yet we somehow can intuit the situation: the evocation of loneliness, helplessness, philosophical and imaginative uncertainty, awareness of the infinite choices made in time.

In Genesis and Coriolanus these concerns are dramatized more concretely. But the resigned acceptance of the darkness and the ignorance of the Ego and Id are still present, as in "Abraham and Orpheus." The images in that poem, as in so many other lyrics ("The Heavy Bear" and "In the Naked Bed, in Plato's Cave," for instance), have an uncertain focus, the dreamlike intensity of surrealism. (His stories, of course, develop this magnificently"In Dreams Begin Responsibilities" and "The Statues" being two famous examples.) But I should guess that they derive less from "surrealism" than from the monumental symbolism of Yeats and the fragmented and allusive symbolism of Eliot. Typically, Delmore evokes images of the city that are both dehumanizing and terrifying but also form the backdrop for his heightened awareness of himself as vulnerable and fragile. They have something of the disembodied, vacant quality of Edward Hopper's paintings. They also express specifically Delmore's intense insomniac sense of the terrors of night and the qualified promises of early morning.

I shudder in the traffic, buildings stand,

Will fall and night will fall, the electric light be snapped

To spread its yellow genius on the floor ... 
No longer the grandstand, nor the balcony,

Nor the formal window gives me cool perspective ...

("Abraham and Orpheus")

The ceiling lightened again, the slanting diagram

Slid slowly forth. ...

The stony street

Displayed the stillness in which buildings stand,

The street-lamp's vigil and the horse's patience.

... Morning, softly

Melting the air, lifted the half-covered chair

From underseas, kindled the looking-glass,

Distinguished the dresser and the white wall.

The bird called tentatively, whistled, called,

Bubbled and whistled, so! Perplexed, still wet

With sleep, affectionate, hungry and cold. So, so,

$O$ son of man, the ignorant night, the travail

Of early morning, the mystery of beginning

Again and again,

while History is unforgiven.

("In the Naked Bed, in Plato's Cave")

The last line of that poem is the key to understanding the themes of Delmore's work that I am emphasizing: his lyric evocations of solitude, of great imaginative masters, of obsession with being caught in a twilight world between past, present, and future. He is constantly dissolving the distinction between universal and personal history. Shadowy philosophers (Plato, Socrates, Marx, Freud, James, Whitehead, Aristotle) are evoked throughout his work to bear witness to events and moods that in themselves appear mysterious, impulsive, melancholy, retrospective. They are appealed to, in effect, to impose intellectual order on a patchwork and exhausted self that yet has immortal longings for beauty, tenderness, grace, and power. Yet these longings too often appear to disguise a brutish, angry, and resentful self. Hence the eloquent plea of "The Heavy Bear":

That inescapable animal walks with me

Has followed me since the black womb held, Moves where I move, distorting my gesture,

A caricature, a swollen shadow,

A stupid clown of the spirit's motive....

Here Delmore conceives of the self almost as a neo-Platonic spirit which begs release from the gross material (and the womb) enclosing it. 
This imprisonment is found not only in the self but also in the family. The figure of the dominant but sinister father is everpresent, of course, in Genesis. But his symbolic presence is felt everywhere. He is softened in the philosopher-presences, but is still judging and overseeing. The mother is the soft, inviting figure for the child to hide in, to protect him from the father and the turbulent complexities of the outside world, especially the world of the city. Moreover, the family itself is connected to the concept of historical determinism, the family and history forming an intricate tissue that the poet cannot escape from, though he would like to. As in "The Ballad of the Children of the Czar," Delmore places the psychological issue clearly in the historical context: that of his own Rumanian grandfather, the events of the Russian revolution, and his family's uncertain place in America:

The child is Aeneas again;

Child labor! The child must carry

His fathers on his back.

The wheeling, whirling world

Makes no will glad.

A pitiless, purposeless Thing,

Arbitrary and unspent ...

The innocent are overtaken,

They are not innocent.

They are their father's fathers, The past is inevitable.

I am overtaken by terror

Thinking of my father's fathers, And of my own will.

This antagonism between his tormented self-willful, impulsive, yet knowing his own psychological entrapment-and his view of history as "unfor- 
given," as a determinist force that he cannot escape, and of his family that he is inextricably if rebelliously part of, is the dominant theme of Delmore's work. He is-though the phrase is overworked-the Alienated Man.

Yet there is a strong countermovement to this alienation. It is his romantic lyricism, deeply melancholy but at the same time celebrating the transcendent power of the self over circumstance and the very determinism that oppresses him. This lyric transcendence is best expressed in the title of his selected poetry-Summer Knowledge. Specifically, it is the idea of ripeness, the full maturity of a moment of perception that sees life as beautiful and whole and precious. This reaches one peak in the prose interlude in Coriolanus called "Pleasure," in which he evokes the joys of being alive as a response to the tragedy of Coriolanus himself. Yet one should note that even here, in his manic phase, so to speak, Delmore knows that he must recall the everpresence of the deterministic and tragic.

Pleasure believes in friends, pleasure creates communities, pleasure crumbles faces into smiles, pleasure links hand in hand, pleasure restores, pain is the most selfish thing. And yet, I know, all this is nothing, nothing consoles one, and our problem and pain are still before us.

Later, in "The Kingdom of Poetry" and "Gold Morning, Sweet Prince," the idea of Yeats's "tragic joy" reasserts itself in the long lines that dip and soar. The celebration of Shakespeare is firmly rooted in the metaphor of theater: Shakespeare is the master illusionist whose tragic vision leads the poet to meditate on the waste of human hopes:

Surely the noble, the innocent, the gifted and the brave Sometimes-surely, at times-prevail. Yet if one living soul Is caught by cruelty and killed by trust Whence is our consolation above or before the grave?

The lyric answers to his own tragic questions are offered as simply hopeful evocations of the spirit of Shakespeare-"sovereign and king/of reality, hope and speech"-and the certainty that without hope the human being has no alternative but to "hide in a dark ark, and deny, refuse to believe in hope's consciousness."

Delmore's lyric and romantic hope should be viewed as equipoised throughout his work against the despairing certainty of a deterministic and hopelessly entangled ego, itself caught within the net of history and family. The poet's task is essentially "a fixed hallucination / Made by the passion of imagination," as the Chorus finally comments on the plight of the "Sleepless Atlantic Boy," Hershey Green, at the end of Genesis. The 
central perception left in that poem is that all experience is passing and is to be held in deep suspicion at the same instant that it is relished.

I have remarked that Delmore's poetry consciously works with the themes of personal history set against the stream of universal history that he sees as deterministic. As a literary critic, he chooses his subjects and makes his emphasis in a similar direction. Part of this emphasis takes the form in the general essays of elucidating the phenomenon of isolation in modern poetry. Much could be said negatively about Delmore's elaboration of commonplace ideas. Yet the very fact that he takes pains to remind his readers of what they may take for granted is a sign of the importance the issues had for him. Modernism, in fact, is the condition which Delmore thought he must define and redefine, no matter if the subject be meter or metaphor, or the themes typical of the pre-Romantic or post-Romantic imaginations. In the large scope of his exposition in such essays as "The Isolation of Modern Poetry" and "Views of a Second Violinist," he is concerned in fact with a broad philosophical context for any specific focus taken up within the essay. (We should also remember that Delmore's most intense and lasting academic training was in classical philosophy.) He argues with great precision and a sense of the importance of the commonplace, for instance, that from the "isolation of poetic sensibility the obscurity of modern poetry also arises."

The poet is engaged in following the minutest movements, tones, and distinctions of his own being as a poetic man. Because this private life of his sensibility is the chief subject available to him, it becomes increasingly necessary to have recourse to new and special uses of language.

(“The Isolation of Modern Poetry")

This is a comment not only on the general historical shift he is elucidating but also on his own sensibility. But as an extremely tactful essayist, he steadfastly avoids discussing himself or his own work. In this fastidiousness he is like his critical and poetic mentor, Eliot, whose authoritative detachment he consistently admired.

While dwelling upon the broad questions of the modern poet's enforced individual sensibility in his general essays, Delmore also consistently emphasizes particularities of tone, rhythm, diction, and imagery whenever he discusses a particular poet. One of his fascinations with Joyce (whom he considered more poet than novelist) was with Joyce's fidelity in rendering the exact particularities of daily life. Delmore's own poetry turns on ob- 
jects, hints, and private memories-“the street-lamp's vigil and the horse's patience." Yet particularities take on their remembered power because they are touched by mystery. Thus his sympathetic but firm criticism of some of Allen Tate's poetry is that there is "peril" for a poet too much concerned with symbolism and ideas. In one of Tate's poems, for instance, “The symbol, being seen too much as idea, does not yield the images which would give a dramatic existence to the idea, and hence the poet's habitual use of language also stands apart and dislocated from the symbol and the idea" ("The Poetry of Allen Tate"). And yet Delmore so generously recognizes that at his best Tate does achieve luminous concreteness, and the "scope, seriousness, and ambition" of his career serve as a model for what a life of devoted artistry can be. It is this delicate balance between rhetoric, idea, symbol, and felt life which he praises in his three brief essays on Wallace Stevens. Along with his fascination for Stevens's metric-metric being a subject with which Delmore was inexhaustibly fascinated as a teacher as wellis his attention to Stevens as the romantic imagination both overwhelmed and obsessed by the world's abundant images.

To take only one more example of a criticism that strikes close to the heart of his own poetry, we can see that Auden is a figure that challenges his critical resources. Writing of Auden in 1939, Delmore is intent on the man who uses Marxist and Freudian categories for seeing events and individuals in complex relationships with history. $\mathrm{He}$ argues that the concern with radical interpretations of history leads Auden to a mechanical and even childish sense of human personality and motive. He sees Auden's great gifts of language and human sympathy being suppressed by his own ideas, and he asserts:

Only a clean break with the public poet which has been fashioned by a conscious will, and a return to the role of obedience to the passive, subconscious self would, it seems, free Auden from so perilous and immediate a relationship [i.e., with the international radical movement].

Auden's development justified Delmore's criticism.

Examples of Delmore's gifts as a critic could easily be multiplied. My point in this essay is to draw attention to the conscious effort that Delmore made as a critic to be generous to both the ideas and the particular forms that poets and poems took. He was faithful to his sense of history and to the infinite ways poets took in interacting with history. At the same time that he succeeded so admirably in the primary task of the critic to be a good elucidator and a generous spirit, he also succeeded in commenting indirectly on his own dilemmas as a poetic man. He saw his fellow artists 
as he saw himself-trying to find a language faithful to the particular torments of our time that his own life so tragically embodied.

\section{SOURCES}

1 Genesis, Book One. New York: New Directions, 1943.

2 Summer Knowledge: New and Selected Poems, 1938-1958. New York: Doubleday, 1959.

3 Selected Essays of Delmore Schwartz, ed. Donald Dike and David Zucker. Chicago: University of Chicago Press, 1970.

4 Papers of Delmore Schwartz, Collection of American Literature, Beinecke Rare Book and Manuscript Library, Yale University. Quoted by permission, and by permission of the Estate of Delmore Schwartz. 